\title{
Sporadic multiple meningiomas harbor distinct driver mutations
}

\author{
Tareq A. Juratli ${ }^{1,2^{*}} \mathbb{D}$, Insa Prilop ${ }^{1}$, Felix C. Saalfeld ${ }^{3}$, Sylvia Herold ${ }^{4,5,6}$, Matthias Meinhardt ${ }^{6}$, Carina Wenzel ${ }^{6}$, \\ Silke Zeugner ${ }^{4,5,6}$, Daniela E. Aust ${ }^{4,5,6}$, Fred G. Barker 2nd ${ }^{7}$, Daniel P. Cahill ${ }^{2,7}$, Priscilla K. Brastianos ${ }^{8}$, \\ Sandro Santagata ${ }^{9}$, Gabriele Schackert ${ }^{1}$ and Thomas Pinzer $^{1}$
}

In a small fraction of patients, intracranial meningiomas arise as multiple and spatially distinct masses therefore presenting a unique management challenge $[9,12,19]$. A recently-published, (Surveillance, Epidemiology, and End Results) SEER-based study has reported that patients with multiple meningiomas ( $\mathrm{MM}$ ) have substantially reduced overall survival when compared to patients with single meningiomas [14]. Patients may develop multiple meningiomas in sporadic or hereditary forms. Familial syndromes that are commonly associated with $\mathrm{MM}$ are neurofibromatosis type 2 (NF2) and familial meningiomatosis in patients with germline NF2 and SMARCB1 mutations, respectively $[2,15]$. While the mutational landscape of single meningiomas has been extensively studied $[3-5,10,20]$, understanding of the molecular pathogenesis of sporadic MM remains incomplete. Older studies and case reports have reported molecular testing in patients with sporadic MM that have principally been focused on tumors with NF2 mutations [8, 16-18]. However, to our knowledge, no molecular profiling in a case series of spatially separated MM, composed of different histological subtypes, has been performed. The objective of this study is to elucidate the genetic features of sporadic $M M$, defined as the presence of $\geq 2$ spatially separated synchronous or metachronous lesions.

This series includes 17 resected sporadic meningiomas from eight patients (seven females and one male) that

\footnotetext{
*Correspondence: tareq.juratli@uniklinikum-dresden.de

${ }^{1}$ Department of Neurosurgery, University Hospital Carl Gustav Carus, Technische Universität Dresden, Fetscherstr. 74, 01307 Dresden, Germany Full list of author information is available at the end of the article
}

were identified by a record search for patients with MM. All patients presented with synchronous, spatially separated meningiomas without evidence of tumor bridging, as reviewed on MR-imaging. The patients had no significant prior radiation exposure and the tumors did not arise in patients who met the clinical criteria for the diagnosis of familial schwannomatosis or neurofibromatosis type 2 [6]. In addition, upon reviewing cranial and spinal MR images, no patient had other intra- or extracranial tumors associated with hereditary meningioma syndromes such as schwannomas or ependymomas.

Fresh frozen tumor tissue was available from all 17 meningiomas and was retrieved from the archives of the Institute for Pathology at the University Hospital Dresden upon approval of the local ethics committee. Two board-certified pathologists confirmed the pathologic diagnosis of each case. All tumors were classified according to the $2016 \mathrm{WHO}$ classification of tumors of the central nervous system [11]. The tumor DNA was purified using AllPrep ${ }^{\circledR}$ DNA Universal Kit for fresh frozen tissue (Qiagen, Germantown MD) following the manufacturer's instructions. The regions of interest were amplified using a custom designed amplikon panel according to the protocol "QIAseq Targeted DNA V3 Panel, May 2017" (QIAGEN, Hilden, Germany). The panel was custom-designed by our group and manufactured by QIAGEN. The panel covers either mutation hotspots or-where loss of function is a known mechanism of action-whole genes. The following meningioma-relevant genes are included: $A K T 1, A T R X, C D K N 2 A, K L F 4$, NF1, NF2, PIK3CA, PIK3R1, POLR2A, PTEN, SMARCB1, SMO, STAG2, SUFU, TP53, TRAF7, and TERT promotor. original author(s) and the source, provide a link to the Creative Commons licence, and indicate if changes were made. The images or other third party material in this article are included in the article's Creative Commons licence, unless indicated otherwise in a credit line to the material. If material is not included in the article's Creative Commons licence and your intended use is not permitted by statutory regulation or exceeds the permitted use, you will need to obtain permission directly from the copyright holder. To view a copy of this licence, visit http://creativecommons.org/licenses/by/4.0/. The Creative Commons Public Domain Dedication waiver (http://creativeco mmons.org/publicdomain/zero/1.0/) applies to the data made available in this article, unless otherwise stated in a credit line to the data. 
During library preparation unique molecular barcodes and sample specific indices were incorporated according to the protocol. Indexed libraries were then quantified using a Qubit dsDNA HS Assay Kit (Thermo Fisher Scientific, MA, USA) and paired end sequenced (2x200 bp) on Illumina MiSeq platform. HG19 was used as reference genome for bioinformatic analyses. The bioinformatics evaluation was performed using the Biomedical Workbench from CLC (12.0.3) using a customized analysis algorithm with following filters: coverage $>/=100$, allele frequency $>/=5 \%$. Notably, we performed internal NGS controls for identity check and cross contamination checks to assure the assignment of the correct samples.

The average age at presentation was 60 years (range 43-75 years) which is comparable with the age of patients with single sporadic meningiomas [9]. Six patients $(75 \%)$ underwent two surgeries within 2 years for tumor resection, whereas in two patients the meningiomas were removed at the same time (patients 1 and 7). Fourteen meningiomas were WHO grade $1(82.3 \%)$ and the remaining three tumors were $\mathrm{WHO}$ grade 2 . This is consistent with previous reports of the predominance of WHO grade 1 among MM [13, 19].

Most importantly, the same mutation was not identified in separate tumors from the same patient, suggesting genomically distinct molecular drivers and an independent origin of these multiple lesions. All but two cases harbored TRAF7, AKT1, SMO or PIK3CA mutations (Fig. 1). The most frequent driver mutations in our series were TRAF7 ( $\mathrm{n}=5)$, PIK3CA H1047R and E545G $(\mathrm{n}=3), A K T 1$ E17K $(\mathrm{n}=3), N F 2(\mathrm{n}=2), S M O$ L412F (one case) and NF1 (one case). We did not detect a known driver mutation in only one meningioma (MM \#3, Site B; Table 1). Interestingly, with the exception of one patient (MM \#5), all tumors from the same patient were different histopathological subtypes (Table 1).

The low frequency of NF2 mutations in our MM series stands in contrast to previous studies that included hereditary cases arising in the setting of NF2 $[2,15,16$, 18]. Those studies identified a high prevalence of $N F 2$ mutations (up to $83 \%$ ) and supported a monoclonal origin for MM $[8,18]$. Our findings in a cohort of $17 \mathrm{MM}$ arising in patients without NF2 support a model in which sporadic MM can arise independently from one another, while a subset of MM may result from somatic NF2 mosaicism [7].

Each of the meningiomas in our study exhibited features that are commonly seen in solitary meningiomas, demonstrating strong associations between the genetic alteration, the histologic subtype and the anatomic location $[1,5,21]$. The high frequency of known and targetable drivers of meningioma in our cohort suggests that a large fraction of MM may be candidates for study in clinical trials evaluating targeted therapies, such as the ongoing multicenter phase II study (ClinicalTrials.gov NCT02523014) that investigates the efficacy of afuresertib in AKT1-mutant, vismodegib in SMO-mutant and the focal adhesion kinase (FAK) inhibitor GSK2256098 in NF2-mutant meningiomas. Given the inter-tumor and intra-patient heterogeneity that we observe in the setting

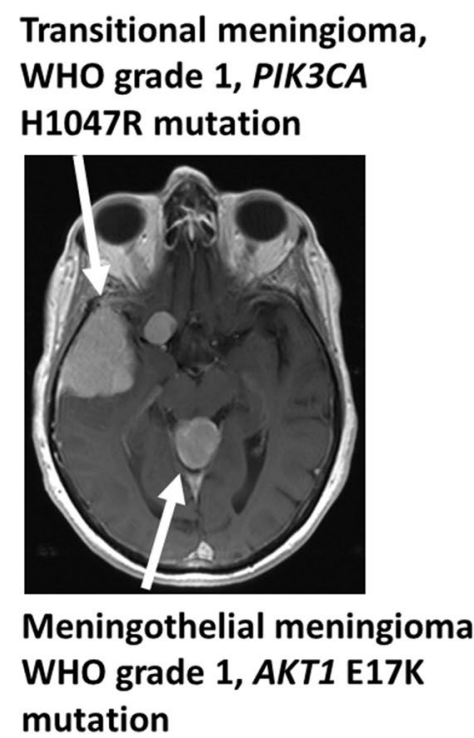

MM \#4

\section{Meningothelial meningioma, WHO grade 1,} SMO L412F mutation

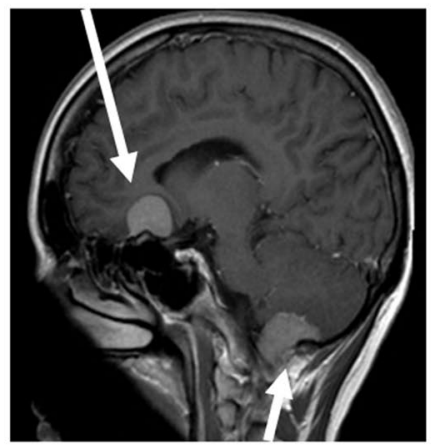

Meningothelial meningioma, WHO grade 1, POLR2A mutation
Transitional meningioma, WHO grade 1, PIK3CA E545G and TRAF7 mutations

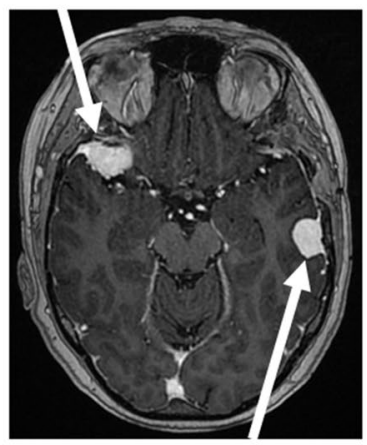

Fibrous meningioma, WHO grade 1, PIK3CA H1047R mutation

Fig. 1 Illustrative cases from three patients with seven meningiomas are shown. No separate tumors within individual patients shared driver mutations 
Table 1 Patients' and tumor characteristics

\begin{tabular}{|c|c|c|c|c|c|c|c|}
\hline Patient & Age (years) & Sex & Tumor site & Tumor location & WHO grade & Histologic features & $\begin{array}{l}\text { Mutations and allele frequency } \\
\text { (\%) }\end{array}$ \\
\hline \multirow[t]{2}{*}{ MM\#1 } & 71 & $\mathrm{~F}$ & Site-A & Infratentorial (L) & 1 & Transitional & AKT1 p.E17K (33\%) \\
\hline & & & Site-B & Petroclival (L) & 1 & Meningothelial & TRAF7 p.K615N (29\%) \\
\hline \multirow[t]{2}{*}{ MM\#2 } & 43 & $\mathrm{~F}$ & Site-A & Convexity (R) & 1 & Microcystic & NF1 p.F384L (5\%) \\
\hline & & & Site-B & Anterior SB (L) & 1 & Meningothelial/transitional & NF2 p.A325fs (37\%) \\
\hline \multirow[t]{2}{*}{ MM\#3 } & 62 & M & Site-A & Convexity (R) & 2 & Atypical & NF2 p.E541* (32\%) \\
\hline & & & Site-B & Petrosal (R) & 1 & Fibrous & None \\
\hline \multirow[t]{2}{*}{ MM\#4 } & 70 & $\mathrm{~F}$ & Site-A & Sphenoid wing (R) & 1 & Transitional & PIK3CA p.H1047R (36\%) \\
\hline & & & Site-B & Pineal region (M) & 1 & Meningothelial & AKT1 p.E17K (36\%) \\
\hline \multirow[t]{2}{*}{ MM\#5 } & 49 & $\mathrm{~F}$ & Site-A & Foramen magnum (M) & 1 & Meningothelial & POLR2A p.H439del (26\%) \\
\hline & & & Site-B & Olfactory groove & 1 & Meningothelial & SMO p.L412F (40\%) \\
\hline \multirow[t]{3}{*}{ MM\#6 } & 53 & $\mathrm{~F}$ & Site-A & Sphenoid wing (R) & 1 & Transitional & $\begin{array}{l}\text { PIK3CA p.H1047R (35\%), TRAF7 } \\
\text { p.S537F (38\%) }\end{array}$ \\
\hline & & & Site-B & Planum spenoidale (M) & 1 & Mixed fibrous/meningothelial & PIK3CA p.E545G (30\%) \\
\hline & & & Site-C & Convexity (L) & 1 & Fibrous & PIK3CA p.H1047R (38\%) \\
\hline \multirow[t]{2}{*}{ MM\#7 } & 75 & $\mathrm{~F}$ & Site-A & Petroclival (L) & 2 & Chordoid & AKT1 p.E17K (31\%) \\
\hline & & & Site-B & Foramen magnum (M) & 2 & Transitional & TRAF7 p.R641H (33\%) \\
\hline \multirow[t]{2}{*}{ MM\#8 } & 54 & $\mathrm{~F}$ & Site-A & Convexity $(\mathrm{L})$ & 1 & Meningothelial & TRAF7 p.Q38E (35\%) \\
\hline & & & Site-B & Convexity (R) & 1 & Secretory & $\begin{array}{l}\text { TRAF7 p.N520S (41\%), KLF4 p.K409Q } \\
\text { (40\%) }\end{array}$ \\
\hline
\end{tabular}

$R$ right, $L$ left, $M$ midline

of MM, target lesions should be genomically characterized and not assumed to share molecular alterations with separately resected lesions.

Taken together, our molecular analysis supports the genomic divergence of sporadic $\mathrm{MM}$ and presumably their independent origin. Our findings have important clinical implications for this patient population and suggests molecular stratification of each meningioma lesion in patients with sporadic MM to improve the design of meningioma clinical trials and help improve patient management.

\begin{abstract}
Authors' contributions
T.A.J and T.P.: conception/design. F.C.S., S.H., M.M., C.W., S.Z.: sample sequencing. I.P., F.C.S., S.H., M.M., C.W., S.Z. and D.E.A.: collection and assembly of data. M.M. and D.E.A.: histology confirmation. T.A.J. F.C.S., C.W., S.Z.: data analysis and interpretation. T.A.J., I.P., F.C.S, S.S., D.P.C., F.G.B., and T.P.: manuscript writing. All authors: final approval of manuscript. All authors read and approved the final manuscript.
\end{abstract}

\section{Funding}

None.

\section{Competing interests}

TAJ received honoraria from CSL Behring and Roche Pharma AG unrelated to the submitted work. PKB reports honoraria for consulting from Tesaro, Lilly, Angiochem, and Genentech-Roche; speaker's honoraria from GenentechRoche and Merck; and research funding (to Massachusetts General Hospital) from BMS, Pfizer, Lilly and Merck. DPC reports receiving honoraria from Merck, Lilly and Boston Pharmaceuticals outside the submitted work. SS is a consultant for RareCyte. The remaining authors have no competing interests to disclose.

\begin{abstract}
Author details
${ }^{1}$ Department of Neurosurgery, University Hospital Carl Gustav Carus, Technische Universität Dresden, Fetscherstr. 74, 01307 Dresden, Germany. ${ }^{2}$ Translational Neuro-Oncology Laboratory, Department of Neurosurgery, Massachusetts General Hospital, Harvard Medical School, Boston, MA, USA. ${ }^{3}$ Clinic of Internal Medicine I, Dresden University Hospital, Dresden, Germany. ${ }^{4}$ Core Unit for Molecular Tumor Diagnostics (CMTD), National Center for Tumor Diseases Dresden (NCT/UCC), Dresden, Germany. ${ }^{5}$ Biobank Dresden, National Center for Tumor Diseases Dresden (NCT/UCC), Dresden, Germany. ${ }^{6}$ Department for Pathology, Dresden University Hospital, Dresden, Germany. ${ }^{7}$ Department of Neurosurgery, Massachusetts General Hospital, Harvard Medical School, Boston, MA, USA. ${ }^{8}$ Division of Hematology/Oncology, Department of Neurology, Stephen E. and Catherine Pappas Center for Neuro-Oncology, Massachusetts General Hospital, Harvard Medical School, Boston, MA, USA.

${ }^{9}$ Department of Pathology, Brigham and Women's Hospital, Boston, MA, USA.
\end{abstract}

Received: 3 December 2020 Accepted: 23 December 2020

Published online: 06 January 2021

\section{References}

1. Abedalthagafi M, Bi WL, Aizer AA, Merrill PH, Brewster R, Agarwalla PK, Listewnik ML, Dias-Santagata D, Thorner AR, Van Hummelen P et al (2016) Oncogenic PI3K mutations are as common as AKT1 and SMO mutations in meningioma. Neuro Oncol 18:649-655. https://doi.org/10.1093/neuon c/nov316

2. Bacci C, Sestini R, Provenzano A, Paganini I, Mancini I, Porfirio B, Vivarelli R, Genuardi M, Papi L (2010) Schwannomatosis associated with multiple meningiomas due to a familial SMARCB1 mutation. Neurogenetics 11:73-80. https://doi.org/10.1007/s10048-009-0204-2

3. Bi WL, Greenwald NF, Abedalthagafi M, Wala J, Gibson WJ, Agarwalla PK, Horowitz P, Schumacher SE, Esaulova E, Mei Y et al (2017) Genomic landscape of high-grade meningiomas. NPJ Genom Med 2:1-14. https:// doi.org/10.1038/s41525-017-0014-7

4. Brastianos PK, Horowitz PM, Santagata S, Jones RT, McKenna A, Getz G, Ligon KL, Palescandolo E, Van Hummelen P, Ducar MD et al (2013) 
Genomic sequencing of meningiomas identifies oncogenic SMO and AKT1 mutations. Nat Genet 45:285-289. https://doi.org/10.1038/ng.2526

5. Clark VE, Erson-Omay EZ, Serin A, Yin J, Cotney J, Ozduman K, Avşar T, Li J, Murray PB, Henegariu O et al (2013) Genomic analysis of non-NF2 meningiomas reveals mutations in TRAF7, KLF4, AKT1, and SMO. Science 339:1077-1080. https://doi.org/10.1126/science.1233009

6. Coy S, Rashid R, Stemmer-Rachamimov A, Santagata S (2020) An update on the CNS manifestations of neurofibromatosis type 2. Acta Neuropathol 139:643-665. https://doi.org/10.1007/s00401-019-02029-5

7. Evans DG, Watson C, King A, Wallace AJ, Baser ME (2005) Multiple meningiomas: differential involvement of the NF2 gene in children and adults. J Med Genet 42:45-48. https://doi.org/10.1136/jmg.2004.023705

8. Heinrich B, Hartmann C, Stemmer-Rachamimov AO, Louis DN, MacCollin M (2003) Multiple meningiomas: investigating the molecular basis of sporadic and familial forms. Int J Cancer 103:483-488. https://doi. org/10.1002/ijc.10840

9. Huang H, Buhl R, Hugo HH, Mehdorn HM (2005) Clinical and histological features of multiple meningiomas compared with solitary meningiomas. Neurol Res 27:324-332. https://doi.org/10.1179/016164105X39932

10. Juratli TA, McCabe D, Nayyar N, Williams EA, Silverman IM, Tummala SS, Fink AL, Baig A, Martinez-Lage M, Selig MK et al (2018) DMD genomic deletions characterize a subset of progressive/higher-grade meningiomas with poor outcome. Acta Neuropathol 136:779-792. https://doi. org/10.1007/s00401-018-1899-7

11. Louis DN, Perry A, Reifenberger G, von Deimling A, Figarella-Branger D, Cavenee WK, Ohgaki H, Wiestler OD, Kleihues P, Ellison DW (2016) The 2016 World Health Organization Classification of Tumors of the Central Nervous System: a summary. Acta Neuropathol 131:803-820. https://doi. org/10.1007/s00401-016-1545-1

12. Nakasu S, Hirano A, Shimura T, Llena JF (1987) Incidental meningiomas in autopsy study. Surg Neurol 27:319-322. https://doi.org/10.1016/00903019(87)90005-x

13. Pereira BJA, de Almeida AN, Paiva WS, de Aguiar PHP, Teixeira MJ, Marie SKN (2020) Natural history of intraventricular meningiomas: systematic review. Neurosurg Rev 43:513-523. https://doi.org/10.1007/s1014 3-018-1019-0

14. Ramos-Fresnedo A, Domingo RA, Vivas-Buitrago $T$, Lundy $L$, Trifiletti DM, Jentoft ME, Desai AB, Quinones-Hinojosa A (2020) Multiple meningiomas: does quantity matter? A population-based survival analysis with underlined age and sex differences. J Neurooncol. https://doi.org/10.1007/ s11060-020-03620-7

15. Rouleau GA, Wertelecki W, Haines JL, Hobbs WJ, Trofatter JA, Seizinger BR, Martuza RL, Superneau DW, Conneally PM, Gusella JF (1987) Genetic linkage of bilateral acoustic neurofibromatosis to a DNA marker on chromosome 22. Nature 329:246-248. https://doi.org/10.1038/329246a0

16. Shen Y, Nunes F, Stemmer-Rachamimov A, James M, Mohapatra G, Plotkin S, Betensky RA, Engler DA, Roy J, Ramesh V et al (2009) Genomic profiling distinguishes familial multiple and sporadic multiple meningiomas. BMC Med Genomics 2:42. https://doi.org/10.1186/1755-8794-2-42

17. Sheng HS, Shen F, Zhang N, Yu LS, Lu XQ, Zhang Z, Fang HY, Zhou LL, Lin J (2019) Whole exome sequencing of multiple meningiomas with varying histopathological presentation in one patient revealed distinctive somatic mutation burden and independent clonal origins. Cancer Manag Res 11:4085-4095. https://doi.org/10.2147/CMAR.S202394

18. Stangl AP, Wellenreuther R, Lenartz D, Kraus JA, Menon AG, Schramm J, Wiestler OD, von Deimling A (1997) Clonality of multiple meningiomas. J Neurosurg 86:853-858. https://doi.org/10.3171/jns.1997.86.5.0853

19. Tsermoulas G, Turel MK, Wilcox JT, Shultz D, Farb R, Zadeh G, Bernstein M (2018) Management of multiple meningiomas. J Neurosurg 128:14031409. https://doi.org/10.3171/2017.2.JNS162608

20. Williams EA, Santagata S, Wakimoto H, Shankar GM, Barker FG 2nd, Sharaf R, Reddy A, Spear P, Alexander BM, Ross JS et al (2020) Distinct genomic subclasses of high-grade/progressive meningiomas: NF2-associated, NF2-exclusive, and NF2-agnostic. Acta Neuropathol Commun 8:171. https://doi.org/10.1186/s40478-020-01040-2

21. Youngblood MW, Duran D, Montejo JD, Li C, Omay SB, Ozduman K, Sheth AH, Zhao AY, Tyrtova E, Miyagishima DF et al (2019) Correlations between genomic subgroup and clinical features in a cohort of more than 3000 meningiomas. J Neurosurg 1:1-10. https://doi.org/10.3171/2019.8.JNS19 1266

\section{Publisher's Note}

Springer Nature remains neutral with regard to jurisdictional claims in published maps and institutional affiliations.
Ready to submit your research? Choose BMC and benefit from:

- fast, convenient online submission

- thorough peer review by experienced researchers in your field

- rapid publication on acceptance

- support for research data, including large and complex data types

- gold Open Access which fosters wider collaboration and increased citations

- maximum visibility for your research: over $100 \mathrm{M}$ website views per year

At BMC, research is always in progress.

Learn more biomedcentral.com/submissions 